\title{
KEPUTUSAN PEMBELIAN DAN PREFERENSI KONSUMEN JERUK PAMELO
}

\author{
W Nahraeni ${ }^{1 \mathrm{a}}$, A Rahayu ${ }^{2}$, A Yusdiarti $^{1}$, Yaskur $^{1}$ \\ ${ }^{1}$ Jurusan Agribisnis, Fakultas Pertanian, Universitas Djuanda Bogor \\ ${ }^{2}$ Jurusan Agrroteknologi, Fakultas Pertanian, Universitas Djuanda Bogor \\ Jalan Tol Ciawi 1, Kotak Pos 35 Bogor 16720 \\ ${ }^{a}$ Korespondensi: Wini Nahraeni Email : wini.nahraeni@unida.ac.id
}

\begin{abstract}
ABSTRAK
Di Indonesia terdapat beragam kultivar pamelo dengan rasa, warna, ukuran dan bentuk buah beragam. Selama ini, usahatani pamelo tidak didasarkan pada preferensi konsumen. Penelitian ini bertujuan untuk menganalisis proses pengambilan keputusan pembelian pamelo dan preferensi konsumen terhadap atribut pamelo. Metode analisis yang digunakan adalah statistik deskriptif. Responden berjumlah 70 orang yang berasal dari Jakarta, Bogor, dan Sukabumi. Hasil analisis menunjukkan bahwa dalam melakukan pembelian, sebagian besar konsumen memilih pasar tradisional, tujuan pembelian adalah mencari variasi buah yang segar dan pencuci mulut, Informasi pembelian berasal dari keluarga, dengan proses pembelian mendadak saat melihat Jeruk Pamelo. Jeruk Pamelo dibeli pada musim tertentu (musim panen), Jumlah Jeruk yang biasa dibeli hanya 1-2 buah tiap pembelian dan sebagian besar konsumen tidak mengetahui kultivar pamelo yang dibeli mereka beli mereka hanya mengetahui bahwa itu adalah Jeruk Bali, Sebagian besar konsumen menyukai pamelo yang memiliki atribut kandungan vitamin banyak, rasa manis, banyak mengandung air (juicy), tekstur empuk/halus, warna daging merah tua, beraroma harum, mempunyai ukuran buah standar (tidak terlalu besar dan tidak terlalu kecil), sepah (graininess) tidak ada, jumlah biji antara sedikit sampai tidak berbiji, dan harga tidak terlalu mahal atau biasa saja. Pengembangan pamelo lebih diprioritaskan pada pamelo yang tidak berbiji dan bersepah sedikit.
\end{abstract}

Kata Kunci: Aksesi Pamelo, Atribut Pamelo, Keputusan pembelian, Preferensi

\section{PENDAHULUAN}

Komoditas hortikultura merupakan komoditas pertanian yang memiliki nilai ekonomi yang tinggi dan sangat berpotensi untuk meningkatkan pendapatan petani, baik skala kecil maupun skala besar. Jeruk(Citrus sp.) adalah tanaman buah tahunan yang berasal dari Asia. Sejak ratusan tahun yang lalu, jeruk sudah tumbuh di Indonesia baik secara alami atau dibudidayakan. Jenis jeruk lokal yang dibudidayakan di Indonesiaadalah jeruk keprok (Citrus reticulate/nobilis L.), jeruk siam (C. microcarpa L. dan C. sinesis L) yang terdiri atas Siam Pontianak, Siam Garut, Siam Lumajang, serta jeruk besar (C. maxima Herr.) yang terdiri atas jeruk
Nambangan-Madium dan Bali (Kementan, 2015)

Pamelo berasal dari Malesia, kemudian menyebar ke Indo-Cina, Cina Selatan, Jepang Selatan, India Barat, Mediterania dan Amerika Tropik (Niyomdham 1992). Walaupun tempat asal pamelo yang tepat tidak diketahui, tetapi kemungkinan besar dari Malaysia, Thailand dan Indonesia, karena di daerah ini banyak dijumpai kerabat liarnya (Thulaja 2003). Kini pamelo telah diproduksi secara komersial di 74 negara baik untuk memenuhi kebutuhan lokal maupun ekspor (Talon dan Gmitter Jr. 2008).

Jawa Timur merupakan salah satu provinsi sentra produksi jeruk besar (pamelo). Salah satu kabupaten penghasil 
pamelo terbesar adalah Kabupaten Magetan. Di Kabupaten Magetan pengusahaan pamelo terutama dilakukan di Kecamatan Bendo, Takeran, Sukomoro dan Kawedanaan. Budidaya pamelo di Magetan tidak hanya di pekarangan, tetapi dilakukan pula di lahan tegalan dan di lahan bekas sawah.

Berbagai aksesi pamelo yang terdapat di Kabupaten Magetan sampai saat ini konsumen tidak mengetahui kualitas dari aksesi pamelo yang dibelinya. Pengetahuan konsumen tentang berbagai aksesi pamelo masih terbatas dan beberapa aksesi juga menurun populasinya, karena karakter buahnya kurang disukai konsumen (misalnya warna daging buah pucat/putih, rasa getir atau masam yang tajam, masa simpan terlalu pendek), sehingga tidak lagi ditanam oleh petani.

Perilaku konsumen adalah proses dan aktivitas ketika seseorang berhubungan dengan pencarian, pemilihan, pembelian, penggunaan, serta pengevaluasian produk dan jasa demi memenuhi kebutuhan dan keinginan. Engel et al. (1994) mendefinisikan perilaku konsumen sebagai tindakan individu yang langsung terlibat dalam usaha mendapatkan, mengkonsumsi, dan menggunakan barang-barang dan jasa termasuk proses pengambilan keputusan yang mendahului dan menentukan tindakan tersebut. Tiga faktor utama yang mempengaruhi proses pembelian yaitu faktor lingkungan, perbedaan individu, dan psikologis.

Penelitian preferensi konsumen telah banyak dilakukan antara lain oleh Adiyoga et al. (2009), Kiloes (2012), Muzdalifah (2012). Namun secara khusus penelitian preferensi buah pamelo relatif belum ada yang meneliti, kecuali secara teknik budidaya dan analisis finansial. Hasil penelitian Adiyoga (2009) menunjukkan pada jeruk siam, atribut rasa dipersepsi konsumen sebagai atribut paling penting (urutan 1) dan harga merupakan urutan terendah. Sebagian besar konsumen menyukai jeruk siam yang memiliki atribut rasa manis, warna kulit hijau, permukaan kulit mengkilat-halus, berkulit tipis dan berserat rendah. Disarankan untuk memperbaiki produktivitas dan kualitas jeruk siam dan adanya perubahan struktur jeruk siam untuk mengimbangi perubahan preferensi konsumen.

Kiloes (2012) dalam penelitiannya diperoleh hasil bahwa kesegaran adalah atribut yang dianggap paling penting oleh konsumen dalam membeli jeruk, diikuti oleh atribut rasa, harga, warna, tekstur, aroma, dan ukuran. Semenara itu Moser et al (2011) menyatakan terdapat perbedaat atribut yang disukai konsumen buahbuahan dan sayuran. Analisis yang berbeda antar negara (USA, Canada, Argentina, Australia, Eropa, Asia Timur (Cina dan Tailand) menyimpulkan bahwa hanya aspek kesehatan yang sama sementara itu atribut lainnya bervariasi antar negara dimana konsumen tinggal.

Oleh karena itu penelitian ini perlu dilakukan untuk mengetahui preferensi keputusan konsumen dalam membeli buah jeruk pamelo dan konsumen terhadap Jeruk Pamelo. Memahami perilaku konsumen buah-buahan merupakan informasi pasar yang sangat penting bagi sektor agribisnis. Informasi ini diperlukan sebagai bahan masukan untuk merencanakan produksi, mengembangkan produk dan memasarkan buah-buahan dengan baik.

Di Kabupaten Magetan telah dilepas lima kultivar pamelo oleh Kementrian Pertanian, yaitu Nambangan, Sri Nyonya, Bali Merah, Magetan dan Gulung. Kultivar pamelo yang paling banyak diusahakan di Kabupaten Magetan adalah 'Nambangan', Di samping kelima kultivar tersebut, masih dijumpai aksesi yang belum dilepas, antara lain Bali Putih, Adas Duku dan Jawa (Rahayu 2012). Paling sedikit telah diketahui tiga aksesi Jawa berbeda ('Jawa 1', 'Jawa 2' dan 'Jawa 3') (Rahayu 2012). Tidak tertutup kemungkinan, masih terdapat aksesi pamelo yang belum diketahui namanya.

Menurut Dhitama, (2002), Pamelo yang dibudidayakan oleh petani pada saat ini hanya didasarkan pada varietas pamelo 
yang memiliki kekuatan dalam daya simpan dan belum mengacu kepada keinginan konsumen. Permaasalahan ini karena petani tidak memiliki informasi pasar terutama mengenai permintaan dan harga. Kualitas buah yang rendah juga menjadi salah satu permasalahan, petani tidak mengetahui kualitas produk dan tidak meningkatkan kualitas hasil sehingga pada kenyataannya di lapang untuk menemukan buah jeruk besar yang memiliki standar kualitas yang baik dan harga yang bersaing.

Berdasarkan uraian tersebut, maka tujuan penelitian ini adalah untuk mengetahui keputusan pembelian jeruk pamelo dan menganalisis atribut-atribut jeruk pamelo yang disukai konsumen

\section{BAHAN DAN METODE}

\section{Lokasi dan Waktu Penelitian}

Penelitian usahatani dan pemasaran telah dilakukan Kecamatan Sukomoro dan Bendo. Penelaahan preferensi konsumen dilakukan di tiga kota yaitu Bogor, Sukabumi dan Jakarta sebagai daerah pemasaran pamelo. Penelitian dilakukan pada bulan Juli - Agustus 2016

\section{Jenis dan Sumber Data}

Data yang digunakan dalam penelitian ini terdiri atas data primer dan data sekunder. Data primer diperoleh dari hasil wawancara dengan responden dengan menggunakan kuesioner yang telah ditetapkan terlebih dahulu. Kuesioner yang disebarkan kepada konsumen berisi pertanyaan-pertanyaan yang meliputi karakteristik responden, dan preferensi konsumen terhadap atribut-atribut pamelo. Karakteristik responden yang dikumpulkan antara lain: umur, jumlah anggota keluarga, tingkat pendidikan, pengalaman, pekerjaan, dan pendapatan per bulan. Data sekunder diperoleh dari instansi terkait meliputi Kementrian Pertanian, Badan Pusat Statistik, Balai Penelitian dan Dinas Pertanian Kabupaten Magetan, serta literatur pendukung baik melalui buku maupun internet.

\section{Metode Penentuan Responden}

Responden pada penelitian ini berjumlah 70 orang, yang tersebar di tiga kota yaitu Bogor. Sukabumi dan Jakarta. Pengambilan responden dilakukan secara purposive yaitu konsumen yang pernah membeli pamelo.

\section{Metoda Analisis Data}

Multi atribut buah pamelo dapat dilihat dari "kriteria mutu" produk buah yang meliputi (1) mutu visual atau penampakkan (2) mouthfeel (rasa di mulut) (3) nilai gizi dan zat berkhasiat (mutu fungsional) (4) keamanan konsumsi, (5) kemudahan penanganan, dan (6) sifat mutu lainnya (Poerwanto, Susanto dan Setyati (2002). Preferensi konsumen didefinisikan sebagai pilihan suka atau tidak suka seseorang terhadap sutu produk. Kotler (1997) menyatakan bahwa preferensi konsumen menunjukkan kesukaan konsumen dari berbagai pilihan produk yang ada.

Dalam penelitian ini analisis data dilakukan secara kualitatif dan kuantitatif. Metode analisis yang digunakan untuk melihat keputusan pembelian konsumen dan preferensi dilakukan secara deskriptif. Data diolah dengan menggunakan SPSS 20. Atribut kunci yang digunakan dalam penelitian ini ada 10 atribut yaitu harga, rasa, ukuran buah, warna daging buah, jumlah biji, aroma buah, tekstur, juiciness, graininess, dan kandungan vitamin.

\section{HASIL DAN PEMBAHASAN}

\section{Karakteristik Responden Konsumen Pamelo}

Karakteristik konsumen Jeruk Pamelo digambarkan melalui umur, jenis kelamin, tingkat pendidikan, jenis pekerjaan, pendapatan dan jumlah tanggungan keluarga. Hasil analisis pada Tabel 1 menunjukkan bahwa responden sebagian besar didominasi oleh wanita, usia berada pada kisaran umur 30-39 tahun $(25,7 \%)$, dengan tingkat bendidikan sebagian besar responden adalah Sarjana 
(S1). Berdasarkan jenis pekerjaan, sebagian besar responden adalah ibu rumah tangga $(35,7 \%)$. Pegawai swasta $(32,9 \%)$ dan yang terendah $(2,9 \%)$ pedagang. Dilihat dari tingkat pendapatan keluarga, sebagian besar responden berada pada kisaran pendapatan Rp1.000.000 - Rp4.000.000 (97,2\%), dengan jumlah tanggungan keluarga sebagian besar (70\%) berjumlah 1-4 orang.

Tabel 1 Karakteristik Responden Preferensi Konsumen, 2016

\begin{tabular}{|c|c|c|c|}
\hline Variabel & Karakteristik Responden & Frekuensi & Persentase $(\%)$ \\
\hline \multirow{3}{*}{ Jenis Kelamin } & Pria & 13 & 18,6 \\
\hline & Wanita & 57 & 81,4 \\
\hline & Jumlah & 70 & 100 \\
\hline \multirow[t]{7}{*}{ Usia (Tahun) } & $<20$ & 1 & 1,4 \\
\hline & $21-29$ & 14 & 20 \\
\hline & $30-39$ & 18 & 25,7 \\
\hline & $40-49$ & 16 & 22,9 \\
\hline & $50-59$ & 16 & 22,9 \\
\hline & $>60$ & 5 & 7,1 \\
\hline & Jumlah & 70 & 100 \\
\hline \multirow[t]{7}{*}{ Pendidikan (tahun) } & SD & 6 & 8,6 \\
\hline & SLP & 9 & 12,9 \\
\hline & SLA & 19 & 27,1 \\
\hline & $\mathrm{S} 1$ & 27 & 38,6 \\
\hline & S2 & 6 & 8,6 \\
\hline & S3 & 3 & 4,3 \\
\hline & Jumlah & 70 & 100 \\
\hline \multirow[t]{6}{*}{ Pekerjaan } & IRT & 25 & 35,7 \\
\hline & Pedagang & 2 & 2,9 \\
\hline & Pegawai Negeri & 18 & 25,7 \\
\hline & Pegawai Swasta & 23 & 32,9 \\
\hline & Lainnya & 2 & 2,9 \\
\hline & Jumlah & 70 & 100 \\
\hline \multirow[t]{4}{*}{$\begin{array}{l}\text { Jumlah Tanggungan } \\
\text { Keluarga (Orang) }\end{array}$} & tidak ada tanggungan & 10 & 14,3 \\
\hline & $1-4$ & 49 & 70 \\
\hline & $5-8$ & 11 & 15,7 \\
\hline & Jumlah & 70 & 100 \\
\hline \multirow[t]{5}{*}{ Pendapatan (Rp) } & $<1$ & 1 & 1,4 \\
\hline & $1.00-2.00$ & 34 & 48,6 \\
\hline & $3.00-4.00$ & 34 & 48,6 \\
\hline & $>5.00$ & 1 & 1,4 \\
\hline & Jumlah & 70 & 100 \\
\hline
\end{tabular}

Keputusan Pembelian Konsumen Jeruk Pamelo

a. Tempat Pembelian Konsumen Jeruk Pamelo

Proses pengambilan keputusan untuk mengkonsumsi Jeruk Pamelo dipengaruhi oleh karaktersitik yang berbeda. Keputusan konsumen dalam menentukan tempat pembelian pamelo dapat dilihat pada Tabel 2. Berdasarkan hasil dari Tabel 2, tempat yang paling banyak dikunjungi responden untuk membeli adalah pasar tradisional, dikuti pedagang keliling, toko buah dan membeli 
pamelo dari petani atau tetangga ketika sedang musim panen.

Sebagian besar konsumen membeli pamelo di pasar tradisional dengan beberapa alasan antara lain: dekat dengan rumah, sekalian membeli kebutuhan lainnya, lebih banyak pilihan untuk ukuran, dan harga. Supermarket dipilih konsumen sebagai tempat pembelian dengan alasan kualitas lebih terjamin, sedangkan pembelian di toko buah dilakukan dengan alasan lebih higyenis, praktis, kesegarannya terjamin,.

Tabel 2. Distribusi Responden Berdasarkan Tempat Pembelian, 2016

\begin{tabular}{llccl}
\hline No & Tempat Pembelian & $\begin{array}{c}\text { Jumlah } \\
\text { (Orang) }\end{array}$ & $\begin{array}{c}\text { Persentase } \\
(\%)\end{array}$ & Alasan \\
\hline 1 & Pasar tradisional & 34 & 48,6 & lebih murah lokasinya dekat \\
2 & Supermarket & 6 & 8,6 & kualitas terjamin \\
3 & Toko buah & 8 & 11,4 & lebih fresh dan bisa dicoba \\
& Pedagang keliling/mobil & 18 & 25,7 & mendadak ketika diinginkan \\
& pinggir jalan & 4 & 5,7 & lebih segar langsung dari pohon \\
& Petani, tetangga & 70 & 100.0 & \\
& Total & & & \\
\hline
\end{tabular}

b. Motivasi Pembelian Konsumen Jeruk Pamelo

Motivasi konsumen untuk membeli Jeruk Pamelo didorong oleh keinginannya untuk mencari variasi buah $(61,4 \%)$, sumber vitamin $(28,6 \%)$, dan kebiasaan keluarga $(7,1 \%)$, Konsumen yang senang buah-buahan terutama jeruk terdorong untuk membeli pamelo karena selain memiliki rasa buah yang segar, pamelo juga mengandung banyak air sehingga dapat menambah kesegaran.

Tabel 3. Distribusi Konsumen Menurut Motivasi Pembelian, 2016

\begin{tabular}{clcc}
\hline No & Motivasi Pembelian Pamelo & Jumlah (Orang) & Persentase (\%) \\
\hline 1 & Kebiasaan keluarga & 5 & 7,1 \\
2 & Mencari variasi buah & 43 & 61,4 \\
3 & Sumber vitamin & 20 & 28,6 \\
4 & Kesegaran rasa & 1 & 1,4 \\
5 & Lainnya (kesukaan) & 1 & 1,4 \\
& Total & 70 & 100,0 \\
\hline
\end{tabular}

c. Alasan Pembelian Konsumen Jeruk Pamelo

Tabel 4 memperlihatkan distribusi responden menurut alasan pembelian. Sebagian besar konsumen $(52,9 \%)$ tertarik membeli Jeruk Pamelo karena rasanya yang segar, 21,4\% karena warna daging buah nya, $18,6 \%$ karena ukurannya, 4,3\% karena harganya, dan hanya $2,9 \%$ tertarik karena penampilannya.

Tabel 4. Distribusi Responden Menurut Alasan Pembelian, 2016

\begin{tabular}{clcc}
\hline No & Alasan Pembelian Jeruk & Jumlah (Orang) & Persentase (\%) \\
\hline 1 & Rasa & 37 & 52,9 \\
2 & Warna & 15 & 21,4 \\
3 & Harga & 3 & 4,3 \\
4 & Ukuran & 13 & 18,6 \\
5 & Penampilan & 2 & 2,9 \\
& Total & 70 & 100,0 \\
\hline
\end{tabular}


d. Manfaat yang Ingin Dicari Konsumen Jeruk Pamelo

Tabel 5 memperlihatkan distribusi responden mengenai manfaat yang dicari dalam mengkonsumsi pamelo. Alasan kesehatan merupakan manfaat yang dicari responden. Sebagian besar konsumen $(47,1 \%)$ menyatakan bahwa mereka mengkonsumsi pamelo untuk pencuci mulut, menjaga kesehatan $37,1 \%$ dan sisanya untuk pemenuhan empat sehat lima sempurna dan kesegaran.

Tabel 5 Distribusi Responden Menurut Manfaat yang Ingin Dicari, 2016

\begin{tabular}{clcc}
\hline No & \multicolumn{1}{c}{ Manfaat } & Jumlah (Orang) & Persentase \\
\hline 1 & Menjaga kesehatan & 26 & 37,1 \\
2 & Pemenuhan 4 sehat 5 sempurna & 5 & 7,1 \\
3 & Pencuci mulut & 33 & 47,1 \\
4 & Lainnya & 6 & 8,6 \\
& Total & 70 & 100,0 \\
\hline
\end{tabular}

e. Informasi Pembelian Pamelo

Konsumen Jeruk Pamelo

Tabel 6 menunjukkan bahwa setelah konsumen mengetahui apa saja yang menjadi kebutuhannya, tahapan selanjutnya adalah mencari informasi untuk memenuhi kebutuhannya. Sumber informasi dalam pembelian Jeruk Pamelo lebih didominasi oleh Keluarga $(51,4 \%)$ diikuti oleh penjual $(22,9 \%)$, informasi dari teman $(14,3 \%)$ dan yang terakhir informasi berasal dari dari iklan $(5,7 \%)$

Tabel 6 Distribusi Menurut Informasi Pembelian Pamelo,2016

\begin{tabular}{clcc}
\hline No & Informasi Pamelo & Jumlah (Orang) & Persentase $(\%)$ \\
\hline 1 & Keluarga & 36 & 51,4 \\
2 & Teman & 10 & 14,3 \\
3 & Penjual & 16 & 22,9 \\
4 & Iklan & 4 & 5,7 \\
5 & Lainnya & 4 & 5,7 \\
& Total & 70 & 100,0 \\
\hline
\end{tabular}

f. Proses Pembelian Konsumen Jeruk Pamelo

Sebagian besar responden melakukan pembelian Jeruk Pamelo secara mendadak ketika diinginkan (60\%), mendadak ketika melihat penjual Jeruk
Pamelo (30\%), Konsumen menyatakan mereka tertarik membeli karena melihat ada penjual pamelo yang dijual dengan menggunakan mobil di pinggir jalan ketika pamelo sedang musim berbuah (Tabel 7).

Tabel 7 Distribusi Menurut Proses Pembelian

\begin{tabular}{clcc}
\hline No & \multicolumn{1}{c}{ Pembeliaan } & Jumlah (Orang) & Persentase (\%) \\
\hline 1 & Terencana & 5 & 7,1 \\
2 & Mendadak ketika diinginkan & 42 & 60,0 \\
3 & Mendadak saat melihat penjual & 21 & 30,0 \\
4 & Lainnya & 2 & 2,9 \\
& Total & 70 & 100,0 \\
\hline
\end{tabular}


g. Frekuensi dan Jumlah Pembelian Konsumen Jeruk Pamelo

Berbeda dengan pembelian jeruk siam yang tersedia setiap hari, pamelo dibeli ketika sedang musimnya. Sebagian besar responden membeli 1-2 kali per bulan, seminggu sekali, 2-3 kali dalam setahun, bahkan $35,7 \%$ menyatakan sudah lama sekali tidak membeli pamelo. Hal ini disebabkan ketika musim berakhir, maka pamelo pun hilang dari pasaran. Jumlah pembelian pamelo dalam satu kali pembelian berkisar $1-2$ buah $(77,1 \%)$ dan hanya 2,9\% membeli 5 - 6 buah karena dibeli untuk kebutuhan syukuran tujuh bulanan

Tabel 8. Distribusi Menurut Frekuensi dan Jumlah Pembelian, 2016

\begin{tabular}{clcc}
\hline No & \multicolumn{1}{c}{ Uraian } & Jumlah (Orang) & Persentase (\%) \\
\hline 1 & Frekuensi pembelian & 2 & \\
& seminggu sekali & 24 & 2,9 \\
& 1-2 kali per bulan & 11 & 34,3 \\
& sekali dalam 2-3 bulan & 8 & 15,7 \\
2-3 kali setahun & 25 & 11,4 \\
lainnya (1-4 tahun sekali) & 70 & 35,7 \\
Total & & 100,0 \\
Jumlah pembelian & 54 & 77,1 \\
1-2 buah & 14 & 20,0 \\
3-4 buah & 2 & 2,9 \\
5-6 buah & 0 & 0,0 \\
>6 buah & 70 & 100,0 \\
Total & &
\end{tabular}

h. Pengetahuan Konsumen Tentang Kultivar Jeruk Pamelo

Menurut Rahayu (2012) terdapat 7 aksesi Jeruk Pamelo dari Kabupaten Magetan yang sudah diketahui. Dari hasil survei di lapangan diperoleh 13 aksesi yang ditanam oleh petani di Kecamatan Sukomoro dan Bendo. Akan tetapi fakta dilapangan sedikit sekali konsumen yang mengetahui bahwa aksesi Jeruk Pamelo yang akan dibelinya ternyata banyak jenisnya. Pengetahuan konsumen akan aksesi Jeruk Pamelo dapat dilihat pada Tabel 9. Berdasarkan hasil wawancara diperoleh hasil sebagian besar konsumen tidak mengetahui aksesi Jeruk Pamelo mana yang akan dibelinya $(87,1 \%)$.

Tabel 14 Distribusi Menurut Pengetahuan Tentang Kultivar

\begin{tabular}{clcc}
\hline No & Pengetahuan Varietas & Jumlah (Orang) & Persentase (\%) \\
\hline 1 & Mengetahui varietas & 9 & 12,9 \\
2 & Tidak mengetahui varietas & 61 & 87,1 \\
& Total & 70 & 100,0 \\
\hline
\end{tabular}

\section{Preferensi Konsumen}

Preferensi konsumen dapat diartikan sebagai pilihan suka atau tidak suka seseorang terhadap suatu produk atau jasa. Preferensi konsumen terhadap Jeruk Pamelo dapat dilihat dari beberapa atributatributnya (Kotler 2014). 
Tabel 10 Jumlah Konsumen yang Memilih Atribut Jeruk Pamelo

\begin{tabular}{lccccc}
\hline \multicolumn{1}{c}{ Atribut } & Nilai & Peringkat & \multicolumn{2}{c}{ Responden yang Memilih Atribut tersebut } \\
\hline Kerata & 4,53 & 1 & $0 \%$ tidak ada & 2,8 sedikit & $97,1 \%$ banyak \\
Rasa buan vitamin & 4,50 & 2 & $0 \%$ asam & $2,8 \%$ asam manis & $97 \%$ manis \\
Juiceness & 4,09 & 3 & $0 \%$ kurang juicy & $10 \%$ biasa & $88,4 \%$ juicy \\
Tekstur buah & 3,94 & 4 & $0 \%$ keras & $17,1 \%$ agak empuk & $82,8 \%$ empuk \\
Aroma buah & 3,69 & 5 & $10 \%$ tidak beraroma & $89,9 \%$ harum & \\
Warna daging buah & 3,84 & 6 & $2,4 \%$ putih kemerahan & $20 \%$ merah muda & $77,1 \%$ merah tua \\
Ukuran buah & 3,64 & 7 & $4,2 \%$ kecil & $41,4 \%$ standar & $54,2 \%$ besar \\
Grainness & 3,34 & 8 & $21,4 \%$ banyak & $37,1 \%$ sedikit & $41,3 \%$ tidak ada \\
Harga & 3,33 & 9 & $15,6 \%$ mahal & $45 \%$ biasa & $38.4 \%$ murah \\
Jumlah biji & 3,14 & 10 & $27,1 \%$ berbiji & $78,7 \%$ tidak berbiji & \\
\hline
\end{tabular}

Tabel 10 menunjukkan bahwa sebagian besar konsumen menyukai pamelo yang memiliki atribut kandungan vitamin banyak, rasa manis, banyak mengandung air (juicy), tekstur empuk/halus, warna daging merah tua, beraroma harum, mempunyai ukuran buah standar (tidak terlalu besar dan tidak terlalu kecil), sepah (graininess) tidak ada, jumlah biji antara sedikit sampai tidak berbiji, dan harga tidak terlalu mahal atau biasa saja.

\section{KESIMPULAN DAN IMPLIKASI KEBIJAKAN}

\section{Kesimpulan}

Dalam melakukan pembelian, konsumen lebih memilih pasar tradisional berkeinginan untuk mencari variasi buah yang segar, sebagai pencuci mulut, Informasi konsumen dalam membeli Jeruk Pamelo berasal dari keluarga, dengan proses pembelian mendadak saat melihat Jeruk Pamelo. Jeruk Pamelo dibeli pada musim tertentu (musim panen), Jumlah Jeruk yang biasa dibeli hanya 1-2 buah tiap pembelian dan sebagian besar konsumen tidak mengetahui kultivar pamelo yang dibeli mereka beli mereka hanya mengetahui bahwa itu adalah Jeruk Bali,

Sebagian besar konsumen menyukai pamelo yang memiliki atribut kandungan vitamin banyak, rasa manis, banyak mengandung air (juicy), tekstur empuk/halus, warna daging merah tua, beraroma harum, mempunyai ukuran buah standar (tidak terlalu besar dan tidak terlalu kecil), sepah (graininess) tidak ada, jumlah biji antara sedikit sampai tidak berbiji, dan harga tidak terlalu mahal atau biasa saja

\section{Implikasi Kebijakan}

'Nambangan' merupakan aksesi yang paling diandalkan oleh petani di Kabupaten Magetan. Sementara bila dilihat dari bobot/jumlah biji, aksesi yang potensial dikembangkan adalah 'Bali Merah 2' dan 'Gulung 1', yang juga memiliki penampilan buah menarik, kandungan vitamin $\mathrm{C}$ tinggi dan rasa manis.

\section{DAFTAR PUSTAKA}

Adiyoga,W., T.Setyowati, M.Ameriana, dan Nurmalinda. 2009. Perilaku Konsumen terhadap Jeruk Siam di Tiga Kota Besar di Indonesia. J. Hortikultura 19(1):112-124.

Dhitama YM. 2002 . Analisis Kelayakan Finanasial Usahatani Jeruk (Citrus Nobilis var Microcarpa) (Studi Kasus Desa sukaras, Kecamatan Samarang, Kabupaten Garut, Jawa Barat). Institut Pertanian Bogor. Bogor

Engel, J. F., R. D. Blackwell dan P. W. Miniard. 1994. Perilaku Konsumen. Edisi Keenam. Jilid 1. Binarupa Aksara. Jakarta.

Kementrian Pertanian. 2015. Outlook Jeruk. Pusat Data dan Sistem Informasi Pertanian. Sekretaris Jendral Kementrian Pertanian ISSN: 1907 1507. Jakarta

Kiloes, A.M. 2012. Penilaian Sikap dan Persepsi Konsumen Terhadap Beberapa Atribut Produk Buah Jeruk 
Lokal dan Impor sebagai Dasar Peningkatan Daya saing Jeruk Nasional. Prosiding Seminar Nasional Pekan Inovasi Teknologi Hortikultura Nasional: Penerapan Inovasi Teknologi Hortikultura dalam Mendukung Pembangunan Hortikultura yang Berdaya Saing dan Berbasis Sumberdaya Genetik Lokal, Lembang, 5 Juli 2012.

Moser R., Roberta Raffaelli and Dawn Thilmany-McFadden. 2011.

Consumer Preferences for Fruit and Vegetables with Credence-Based Attributes: A Review . International Food and Agribusiness Management Review Volume 14, Issue 2, 2011

Muzdalifah. 2012. Kajian Preferensi Konsumen Terhadap Buah-Buahan Lokal di Kota Banjarbaru. Jurnal Agribisnis Pedesaan Volume 02 Nomor 04 Desember 2012
Poerwanto, R., Susanto S., dan S. Setyati, H., 2002. Pengembangan Jeruk Unggulan Indonesia. Makalah Semiloka Nasional Pengembangan Jeruk Unggulan. Bogor $10-11$ 2002.

Rahayu A. 2012. Evaluasi Kualitas Buah Pamelo Berbiji dan Tidak Berbiji Selama Masa Simpan [disertasi].Sekolah Pascasarjana. Institut Pertanian Bogor.

Rahayu, A. 2012. Karakterisasi dan Evaluasi Aksesi Pamelo (Citrusmaxima (Burm.) Merr.) Berbiji dan Tidak Berbiji. [disertasi]. Bogor: Sekolah Pascasarjana IPB.

Sumarwan, U. 2004. Perilaku Konsumen, Teori dan Penerapannya. Ghalia Indonesia, Bogor.

Talon M, Gmitter Jr FG. 2008. Citrus genomics. Review Article. Intl J Plant Genomics.17 p. 